\title{
Impact of abiotic factors on development of the community of arbuscular mycorrhizal fungi in the soil: a Review
}

\author{
Agnieszka Jamiołkowska ${ }^{1}$, Andrzej Księżniak ${ }^{2}$, Anna Gałazka ${ }^{2}$, Beata Hetman ${ }^{1}$, Marek Kopacki ${ }^{1}$ \\ and Barbara Skwaryto-Bednarz ${ }^{1 *}$ \\ ${ }^{1}$ Department of Plant Protection, Faculty of Horticulture and Landscape Architecture, University of Life Sciences in Lublin, \\ Leszczyńskiego 7, 20-069 Lublin, Poland \\ ${ }^{2}$ Department of Agriculture Microbiology, Institute of Soil Science and Plant Cultivation, State Research Institute, \\ Krańcowa 8, 24-100 Puławy, Poland
}

Received February 2, 2017; accepted November 27, 2017

\begin{abstract}
Arbuscular mycorrhizal fungi inhabiting soil play an important role for vascular plants. Interaction between arbuscular mycorrhizal fungi, plants and soil microorganisms leads to many mutual advantages. However, the effectiveness of mycorrhizal fungi depends not only on biotic, but also abiotic factors such as physico-chemical properties of the soil, availability of water and biogenic elements, agricultural practices, and climatic conditions. First of all, it is important to adapt the arbuscular mycorrhizal fungi species to changing environmental conditions. The compactness of the soil and its structure have a huge impact on its biological activity. Soil $\mathrm{pH}$ reaction has a substantial impact on the mobility of ions in soil dilutions and their uptake by plants and soil microflora. Water excess can be a factor negatively affecting arbuscular mycorrhizal fungi because these microorganisms are sensitive to a lower availability of oxygen. Mechanical cultivation of the soil has a marginal impact on the arbuscular mycorrhizal fungi spores. However, soil translocation can cause changes to the population of the arbuscular mycorrhizal fungi abundance in the soil profile. The geographical location and topographic differentiation of cultivated soils, as well as the variability of climatic factors affect the population of the arbuscular mycorrhizal fungi in the soils and their symbiotic activity.

Keyw ords: mycorrhiza, abiotic factors, dynamics of arbuscular mycorrhizal fungi development
\end{abstract}

\section{INTRODUCTION}

Arbuscular mycorrhiza involve a mutualistic symbiosis of vascular plant roots and fungi belonging to the Glomeromycota. The association between mycorrhizal fungi and plant roots was important in the evolution of land plants and currently occurs in at least $80 \%$ of all plant spe-

*Corresponding author e-mail: barbara.skwarylo@up.lublin.pl cies (Smith and Read, 2008). Colonization by arbuscular mycorrhizal fungi (AMF) can provide multiple functions, such as increase nutrient uptake and plant growth, as well as provide protection to the plant against pathogen infection (Ronsheim, 2012). Among the most important factors regulating the dynamics of mycorrhizal development are abiotic environmental factors. Also significant are factors such as temperature, soil $\mathrm{pH}$, humidity and the intensity of light as well as the availability of minerals (Bonfante and Perotto, 1995; Miranda and Harris, 1994; Tahat and Sijam, 2012). The production of spores by AMF causes these fungi to survive and propagate in the soil environment despite the absence of a symbiotic plant.

In the soil environment spores can survive longer, preserving their ability to sporulate and colonize roots, even after several years of dormancy (Smith and Read, 2008). AMF spores contain substances such as lipids, proteins and polysaccharides, necessary as energetic substrates in DNA synthesis and in mitotic divisions of chromatin (Bonfante and Perotto, 1995). A proper condition for AMF spores germination is regarded as their survival ability during long periods of dormancy. In field conditions, AMF spores can survive in dormancy over a year (Smith and Read, 2008). The necessary time of dormancy is determined as 4 to 6 months and depends on the genus and species of the AMF fungus (Gazey et al., 1993). To maintain spores' activity for longer (several years) periods it is recommended that they be stored at the temperature of $4-8^{\circ} \mathrm{C}$ in air-dry soil (Jasper et al., 1993).

(C) 2018 Institute of Agrophysics, Polish Academy of Sciences 
AMF have the ability to achieve limited saprophytic growth; however, without additional signals from the plant, the growth of the fungus is inhibited and contact between the symbionts is not established. The growth of fungal hyphae stops 20-30 days after germination (Giovanetti and Citernesi, 1993; Schreiner and Koide, 1993). The germination of AMF spores depends on numerous factors.

\section{OCCURRENCE OF AMF IN THE SOIL}

Arbuscular mycorrhizal fungi are mainly transported by wind and water, soil translocation resulting from erosion as well as heavy rains and plant residues. Endomycorrhizal fungi colonize all types of soil and their number and the variety of AMF species depend on the type of soil (Table 1).

Biodiversity of AMF is determined with direct (total number, number of spores, microscopic observations) and indirect methods (fungal biomass, enzymatic activities). Changes in genetic diversity that result from various anthropogenic and natural factors can be evaluated using molecular techniques (e.g. ITS PCR, PCR - DGGE, ITS NGS) (Orgiazzi et al., 2013; Schoch et al., 2012). The analysis of a set of genes (genomic DNA) can provide information about the structure and genetic connections of the examined set of AMF (Zholl et al., 2016).

Next Generation Sequencing (NGS) of the hyper alternating regions (ITS Internal Transcribed Spacer) allows one to define the genetic diversity of fungi without cell culture cultivation (Orgiazzi et al., 2013). It consists in the isolation of total DNA from soil sample and the preliminary amplification of hyper alternating regions with the use of specific starters. At next stage, correct adaptors and indexes are attached to amplicons (Lim et al., 2010). Samples concentrations are normalized and then all samples are combined into one cumulative sample designated for sequencing. The use of adequate indexes makes it possible to assign individual amplicons to appropriate samples. Metagenomics analysis is not only aimed at examining the diversity of AMF, but also searching for functional genes hence the evidence for the occurrence of specific metabolic activities among the members of AMF.

T a b l e 1. A summary of the number of AMF species found in the soils of natural and managed ecosystems

\begin{tabular}{|c|c|c|c|}
\hline Environment & Region/Contry & $\begin{array}{l}\text { Species } \\
\text { No. }\end{array}$ & References \\
\hline Forest & $\begin{array}{l}\text { Słowiński National Park/ } \\
\text { Poland }\end{array}$ & 20 & Tadych and Błaszkowski (2000b) \\
\hline Forest (Crataegus pontica) & Ilam Province/Iran & 13 & Mirzaei et al. (2014) \\
\hline Forest & $\begin{array}{l}\text { Tuchola on the Brda river } \\
\text { valley/Poland }\end{array}$ & 25 & Tadych and Błaszkowski (2000a) \\
\hline Grassland & North Carolina/USA & 23 & Bever et al. (1996) \\
\hline Tellgrass prairie & Kansas/USA & 14 & Bentivenga and Hetrick (1992) \\
\hline Rupestrian grassland (1 $400 \mathrm{~m}$ a.s.1.) & Serra do Cipó/Brazil & 27 & Coutinho et al. (2015) \\
\hline Rocky outcrop (1200 m a.s.1.) & Serra do Cipó/Brazil & 34 & Coutinho et al. (2015) \\
\hline Rhizosphere soil (990 - 1845 m a.s.l.) & Tatra Mountains/Poland & 20 & Zubek et al. (2008) \\
\hline Sandy soil & Hel/Poland & 34 & Błaszkowski (1994) \\
\hline Maritime dune & Bornholm/Demnark & 26 & Błaszkowski and Czerniawska (2011) \\
\hline Desert & Błędowska Desert/Poland & 20 & Błaszkowski et al. (2002) \\
\hline Conventional agriculture (Zea maydis) & Minessota/USA & 13 & Kurle and Pfleger (1996) \\
\hline Conventional agriculture (Sorgum bicolor) & Nebraska/USA & 26 & Ellis et al. (1992) \\
\hline Conventional orchard (apple) & Brazil & 20 & Purin et al. (2006) \\
\hline Organic orchard (apple) & Brazil & 30 & Purin et al. (2006) \\
\hline Cultivated soil & Lubuskie region/Poland & 12 & Kowalczyk and Błaszkowski (2005) \\
\hline Non cultivated soil & Lubuskie region/Poland & 15 & Kowalczyk and Błaszkowski (2005) \\
\hline
\end{tabular}


AMF spores were found in both tropical and arctic conditions, in dry and wet lands as well as in natural and artificial conditions (including agrocenoses). A small number or absence of AMF spores is only to be found in chemically treated and physically degraded soils.

Climatic and soil conditions, the plant cover, and the intensity of anthropogenic effect engender substantial diversity in the population and genus composition of AMF spores in various ecosystems (Khalil et al., 1992). Differences can occur between cultivated and non-cultivated soils (fallow and wasteland) as a result of plant rotation and different biochemical and microbiological properties of such soils (Guo et al., 2012; Rillig, 2004).

Fungi from the Glomus genus are common in cultivated soils. Spores belonging to genera Gigaspora and Sclerocytis are more frequent in non-cultivated soils. AMF spores from the Glomus genus predominate in Poland cultivated soils, which might be related to the $\mathrm{pH}$, fertilization and better structure of these soils (Błaszkowski, 1993a,b; Kowalczyk and Błaszkowski, 2011). Data concerning the community of AMF in agricultural soils is varied due to the fact that the spore population is largely affected by plant cultivation in the rotation system, the cyclical nature of agrotechnical treatments, and chemical crop protection (Land and Schonbeck, 1991). In consequence, the use of soil for agricultural purposes does not always promote the occurrence of AMF spores. In Polish soils more AMF spores were found in the rhizosphere of cultivated plants as compared to the non-cultivated soil from the rhizosphere of plants growing in the wild (Błaszkowski, 1993a,b; Kowalczyk and Błaszkowski, 2011). Agrotechnical treatments affect the selection of AMF species and put additional pressure on the adaptation of native AMF to the changing soil conditions (Rilling, 2004).

The studies on the communities of endomycorrhizal fungi revealed that the level of colonization of plant roots was not usually correlated with the population of spores in the soil (Khalil et al., 1992; Oehl et al., 2005). The distribution of mycorrhizal fungi spores in the soil profile depends on the degree of soil penetration by the roots of the host plant. For this reason, the largest populations of spores in cultivated soils were found up to $15 \mathrm{~cm}$ of the profile depth, which is a depth characterized by conditions most conducive to soil processes performed by rhizosphere microorganisms.

The population of AMF spores considerably decreases below $30 \mathrm{~cm}$ of the soil surface. Generally, no spores of AMF were found at depths below $70 \mathrm{~cm}$ (Oehl et al., 2005). However, a number of symbiotic systems between microorganisms and plant roots can appear even deeper, especially in barren and air-drained soils (Guo et al., 1996; Mensah, 2015; Oehl et al., 2005). The topographic field location (e.g. on the slope, in a valley) can also affect the population of AMF spores, which is associated with the nutrient content and the water migration of AMF spores. However, the correlation between field topography and AMF spore populations has not yet been widely recognized (Khalil and Loynacham, 1994).

\section{PHYSICAL AND CHEMICAL PROPERTIES OF SOIL AFFECTING THE SPREAD OF AMF SPORES}

Differentiation of the community of the mycorrhizal fungi largely depends on the content of organic matter, $\mathrm{pH}$ of the soil, and water content in the soil. The soil properties have a significant effect on the population of AMF spores in the soil, irrespective of the geographical location, the manner of soil cultivation and the plant density (Khalil and Loynachan, 1994). Negative correlation was observed between the level of root colonization and the content of the organic matter and phosphorus.

The compactness of the soil and its structure have a considerable impact on its biological activity. Loose soils or soils with a poorly formed arable layer are characterized by marginal biological activity and a low population of AMF spores, and low symbiotic activity is usually observed in those soils (Aziz and Sylvia, 1992). Excessive soil cohesion can also be the cause of unfavorable conditions for the growth of plants and symbiosis with AMF and their sporulation (Camel et al., 1991).

Soil $\mathrm{pH}$ reaction has a major impact on the mobility of ions in soil dilutions and their uptake by plants and soil microorganisms. A decrease of soil $\mathrm{pH}$ in the rhizosphere of mycorrhizal plants can be associated with the fact that AMF hyphae prefer ammonium cations, which at the same time might be a non-specific mechanism of phosphorus mobilization (Bücking and Kafle, 2015). Acid soils create conditions unfavorable to plant growth and AMF activity (Tahat and Sijam, 2012). The soil pH can be a selective factor for the composition of rhizosphere microorganisms in the soil. The soil $\mathrm{pH}$ reaction ranging from 4.5 to 7.5 has no impact on the symbiotic activity of AMF in plant roots (Bücking and Kafle, 2015). The direct impact of the $\mathrm{pH}$ reaction of the soil environment on AMF is limited to the sporulation stages and the germination of AMF spores in the rhizosphere. Much more spores were found in soils with a neutral $\mathrm{pH}(\mathrm{pH}$ 6.5) as compared to soils with $\mathrm{pH}$ 5.5. In strongly acidic soils ( $\mathrm{pH}$ below 4.5 ) a considerable decrease in the number of spores and sometimes their absence was observed (Guo et al., 1996).

\section{ACCESSIBILITY OF WATER AND BIOGENIC ELEMENTS FOR AMF PLANTS}

Water excess can be a factor adversely impacting on AMF because these microorganisms are sensitive to a loer availability of oxygen. Consequently, spores of endomycorrhizal fungi were not usually found in periodically flooded soils (Solaiman and Hirata, 1996). It was proven that with water deficits in the soil, mycorrhizal plants sustained smaller biomass losses than non-mycorrhizal ones. This resulted in an easier uptake of water and mineral 
elements by the hyphae of endomycorrhizal fungi (Birhane et al., 2012). In field conditions, a better yielding of mycorrhizal plants (soybean, alfalfa) cultivated with limited access to water or under periodical drought stress was also obtained (Braunberger et al., 1994).

In conditions of water deficiency a higher photosynthetic activity and nitrogen assimilation was simultaneously observed with a double symbiosis (Rhizobium sp. + AMF) of papilionaceous plants. More recent research on the vegetation of mycorrhizal and non-mycorrhizal plants in drought conditions revealed the highest effectiveness of plants colonized solely by AMF in the uptake of elements (Sanchez-Diaz et al., 1996). Mycorrhizal plant increases its competitiveness in the speed and scope of absorbing biogenic elements from the soil, especially phosphorus (Olsson et al., 1997). The phosphorus-uptake and storage functions are largely taken over by AMF (Köhl et al., 2016; Schachtman et al., 1998). The phosphorus content in the soil seems to play a substantial regulatory role in the plant's growth processes and the effectiveness of symbiosis as well as in regulating the level of root tissue colonization by AMF hyphae (Kowalska et al., 2015).

Much attention is given in literature to the participation of AMF in the uptake of other elements from the soil, especially those which - in conditions of water deficit or excess in the soil - can have an inhibiting or toxic effect on plants. It was shown that mycorrhizal plants take up less manganese than non-symbiotic plants, which can result from a decrease in the reducing properties (manganese) of root exudates of the mycorrhizal plant and a limited activity of microorganism populations taking part in manganese reduction (Posta et al., 1994).

Fungal hyphae can also be a barrier for the translocation of heavy-metal ions to the plant aboveground parts as these ions are immobilized in the root $(\mathrm{Cd}, \mathrm{Ti}$, $\mathrm{Ba}, \mathrm{B}$ ) with the participation of polyphosphates or specific metalloproteins (Nowak and Kunka, 2009; Turnau et al., 1993; Yang et al., 2015). Soil contamination with zinc is also toxic for plants and, at the same time, antagonistic during phosphorus uptake (Ryan and Graham, 2002). AMF, in particular those adapted to higher zinc concentrations in the soil, can limit zinc uptake by plants, while stimulating phosphorus uptake. Therefore, the toxic effect of zinc is reduced in mycorrhizal plants as compared to non-mycorrhizal (Mugabo et al., 2014; Shetty et al., 1995; Tahat and Sijam, 2012). AMF take part in the uptake of iron and zinc by mycorrhizal plants during a deficit of those elements in the soil (Thompson, 1996).

AMF do not only support plants in the uptake of nutritious elements but also produce glomalin, a protein valuable for plants. This glycoprotein commonly occurs in the soil and is a store for carbon whose source is atmospheric $\mathrm{CO}_{2}$ (Wright et al., 1996). Glomalins constitute nearly 30\% of carbon content in the soil and about $2 \%$ of the total weight of soil aggregates (Nichols, 2004). The physico-chemical properties of glomalin such as insolubility, viscosity and hydrophobicity can initiate and protect the appearing soil aggregates and improve the hydrophobic properties of soil particles allowing air permeation and water flow (Gałąka and Gawryjołek, 2015; Wright and Anderson, 2000; Wright et al., 1996). Glycoproteins cover the soil aggregates and protect them from being broken up by forming a characteristic coat on their surface (Wright and Anderson 2000). Glomalins produced by AMF cover the mycelium hyphae, keeping water and nutrients on the way to and from the plant, thus contributing to the better nutrition of plants and to an increased yield (Nichols, 2004; Gałąza and Gawryjołek, 2015).

The ability to produce and store glomalins in fungal hyphae is characteristic exclusively of arbuscular mycorrhizal fungi belonging to order Glomerales, accumulating family Glomeraceae with genus Glomus (Gałąza, 2013; Gałązka and Gawryjołek, 2015). No other fungi except Glomeromycota produce glomalins in considerable quantities. Glomalin is mainly localized on the surface of hyphae and spores of AMF and, being hydrophobic, probably covers the mycelium and protects it against degradation from other microorganisms in addition to increasing durability of the structure of the cell walls of those fungi, and facilitating their spread in the soil. The population and symbiotic activity of AMF, and thus a greater production of glomalin, can be increased both by modification of soil conditions promoting the propagation and activity of spores and by introduction of selected microorganisms into the rhizosphere which promote the process of mycorrhiza (Rillig and Steinberg, 2002).

\section{AGROTECHNICAL FACTORS}

Farming practices have an impact on AM association, damaging or killing AMF and directly, by creating conditions, either favourable or unfavourable to AMF (Table 2).

Mechanical cultivation of the soil has little impact on the population of AMF spores; however, soil translocation can cause changes in the population of AMF spores in the soil profile. Therefore, a decrease in the infection potential of the soil is possible, which is connected with a more difficult germination of certain AMF spores or propagules in the translocated soil (Duponnois et al., 2001). Frequent cultivation treatments connected with crushing the top soil layer might be the reason for a decreased level of colonization of plant roots by AMF. This is related to an increase of the soil density under the effect of the wheels of machines pressing it. This often affects negatively the growth of roots and creates the risk of destruction of the hyphae or physical damage to AMF spores (Abiala et al., 2013; Oehl et al., 2005). In agricultural soils, considerable differentiation in the composition of AMF was observed. This is connected with the methods of cultivation and the scope of additional agrotechnical treatments (Gosling et al., 2006; Mathimaran et al., 2005; Talukdar and Germida, 1994; Vallini et al., 1993). 
T a b l e 2. Organic farm management practices* and their effect on AM association (Gosling et al., 2006)

\begin{tabular}{ll} 
Practices & Effect \\
\hline Beneficial practices & \\
Use of low solubility fertilizers & Low concentration of available nutrients in soil, encourages \\
Exclusion of most biocides & AMF colonization \\
Ley periods & Toxic effects of some biocides on AMF are avoided \\
Diverse rotations & Encourages build up of AMF propagule numbers \\
& Encourages a diverse AMF community
\end{tabular}

Detrimental practices

Mechanical tillage for weed control

Bare fallows

Non-mycorrhizal crops

Use of copper based fungicides

*May not be exclusive to organic farming systems.

\section{CLIMATIC FACTORS}

The geographical location and topographic differentiation of cultivated soils as well as the variability of climatic factors affect the population of AMF in the soils and their symbiotic activity. The optimum temperatures for the activity of AMF is similar to the optimum range for plant vegetation. However, it was observed that the temperature optimum for development stages of AMF (germination, infectiveness of hyphae, formation of arbuscules and vesicules, sporulation) is differentiated. Moreover, differences between AMF species as regards the values of optimum temperatures of spore germination and hyphae infectiveness were observed. These were connected with the origin of fungi strains from different climatic zones (Lekberg and Koide, 2008).

Extremely low or high temperatures in a given region can considerably reduce the population of AMF in the soil (Addy et al., 1994). It was also found that AMF spores isolated from soils in hot climatic zones (India, Egypt, Florida) are less susceptible to a higher temperature of storage as compared to those isolated from soils in moderate climates (England); this indicated the possibility that AMF adapt themselves to climatic conditions as well (Al-Karaki et al., 2004).

Light is a factor which affects mycorrhizas indirectly. It regulates the activity of symbioses mainly through the products of photosynthesis, i.e. carbohydrates transported to the roots (Saia et al., 2015). High light intensity increases root colonization and AMF spore production. On the other hand, shortage of light might cause disturbances in the nutritious balance of symbionts and reduce the level of colonization of plant roots. The prevalence of the daytime period (more than $12 \mathrm{~h}$ ) in the photoperiod cycle also stimulates the process of mycorrhiza and the development of AMF (Lahrmann et al., 2013).

Due to fungi ability to adapt to different environmental conditions, such as temperature, light and humidity, AMF are practically present in the soils of different climactic
Disrupts mycorrhizal hyphal network

Lack of host plants results in decline in propagule numbers Lack of host plants results in decline in propagule numbers Directly toxic to AMF

zones. The effect of adaptation to a definite climate is the ecotypic differentiation of AMF. It is for example expressed in differences in the physiological activity of AMF from various climatic zones despite the morphological affiliation within one species (Hamel et al., 1994). The seasonal character of climactic changes in a given region determines the indirect impact (through a plant) of climactic factors on AMF. This is connected with nutritious relations between endomycorrhizal fungi and plants. Those relations are visible especially in the cultivation of annual or winter plants and they are reflected in the adaptation of the stages of the development of AMF to the seasonably changing plant vegetation (Al-Karaki et al., 2004).

\section{SUMMARY}

The most important abiotic factors affecting the efficiency of arbuscular mycorrhiza include the physico-chemical properties of soil, the availability of water and biogenic elements, agricultural practices, and weather conditions. As regards physico-chemical properties, the following are important: $\mathrm{pH}$, correlation between water and air, and water and sorption capacities of the soil.

The $\mathrm{pH}$ of the soil plays an important role in the mobility of ions in aqueous solutions and their uptake by plants and microorganisms. Generally, a low $\mathrm{pH}$ adversely affects plant growth and development and the growth and activity of AMF. This is probably related to the inhibitory effect of aluminium ions. The excess of water can adversely affect the development of mycorrhiza, because AMF are microorganisms sensitive to reduced oxygen availability. The resistance of mycorrhizal plants to drought depends on the AMF species colonizing plant roots. It is assumed that mycorrhizal fungi can modify the growth of the aerial parts of plants under conditions of drought stress by affecting the plant complex mechanisms of response to water deficit, associated with the uptake of $\mathrm{P}$ and $\mathrm{K}$, the root respiration, photosynthesis, transpiration, and the osmotic potential of leaves. 
One of the most important agricultural treatments is the mechanical cultivation of soil, which has a slight effect on the number of AMF spores; however, the movement of soil can lead to changes in the number of spores in the soil profile. It may cause a decrease in the infection potential of the soil due to the difficulties in the germination of AMF spores in the displaced soil. The geographic and topographic diversity of soils and the variability of climatic factors affect the growth of plants and the quantity of AMF and their symbiotic activity. This applies particularly to temperature, precipitation, photoperiod and light intensity, which change daily and seasonally. The optimum temperature for the AMF activity is similar to temperature for plant growth. However, it was observed that optimum temperature for the different stages of AMF development is varied. The differences in the values of optimum temperature for spores germination and hyphae infectivity between AMF species were also observed. Extremely low or high temperatures can significantly reduce the number of AMF propagules in the soil. The ability of AMF to adapt to climatic conditions was observed.

Light is an indirect factor affecting AMF and one which regulates the activity of symbiosis mainly by transporting assimilates to the roots.

The high intensity of light increases the level of colonization of roots and production of AMF spores, while the deficiency of light energy can cause nutritional disorders in symbionts and decrease the colonization of plant roots. The adaptability of AMF to changing environmental conditions means that these fungi are found in all types of soils in different climate zones. The ecotype variety of AMF is the result of fungi adaptation to changing environmental conditions. This is expressed by the varied physiological activity of AMF coming from different climatic zones. Seasonality of climate changes in the region affects the AMF indirectly. This is due to the discussed developmental and nutritional relationships between endomycorrhizal fungi and plants. These relationships are especially noticeable in the case of annual or winter crops, and expressed through the adaptation of the development stages of AMF to changing seasonal vegetation.

Conflict of interest: The Authors do not declare conflict of interest.

\section{REFERENCES}

Abiala M.A., Popoola O.O., Olawuyi O.J., Oyelude O.J., Akanmu A.O., Killani A.S., Osonubi O., and Odebode A.C., 2013. Harnessing the potentials of Vesicular Arbuscular Mycorrhizal (VAM) fungi to plant growth - A review. Int. J. Pure Appl. Sci. Technol., 14(2), 61-79.

Addy H.D., Schaffer G.F., Miller M.H., and Peterson R.L., 1994. Survival of the external mycelium of a VAM fungus in frozen soil over winter. Mycorrhiza, 5, 1-5.
Al-Karaki G., McMichael B., and Zak J., 2004. Field response of wheat to arbuscular mycorrhizal fungi and drought stress. Mycorrhiza, 14, 263-269.

Aziz T. and Sylvia D.M., 1992. Mycorrhizal amelioration of the detrimental effect of biodune on plant growth. Proc. Soil and Crop Science Society of Florida, 51, 20-23.

Bentivenga S.P. and Hetrick B.A.D., 1992. The effect of prairie management practices on mycorrhizal symbiosis. Mycologia, 84, 522-527.

Bever J.D., Morton J.B., Antonovics J., and Schultz P.A., 1996. Host-dependent sporulation and species diversity of arbuscular mycorrhizal fungi in a mown grassland. J. Ecology, 84, 71-82.

Birhane E., Sterck F.J., Fetene M., Bongers F., and Kuyper T.W., 2012. Arbuscular mycorrhizal fungi enhance photosynthesis, water use efficiency, and growth of frankincence seedlings under pulsed water availability conditions. Oecologia, 169(4), 895-904.

Blaszkowski J., 1993a. Comparative studies of the occurrence of arbuscular fungi and mycorrhizae (Glomales) in cultivated and uncultivated soils of Poland. Acta Mycologica, 28, 93-140.

Błaszkowski J., 1993b. The occurrence of arbuscular mycorrhizal fungi (Glomales) and mycorrhizae in cultivated and uncultivated soils of Poland. Phytopathologia Polonica, 5(17), 9-15.

Blaszkowski J., 1994. Arbuscular fungi and mycorrhizae (Glomales) of the Hel Peninsula, Poland. Mycorrhiza, 5, 71-88.

Błaszkowski J. and Czerniawska B., 2011. Arbuscular mycorrhizal fungi (Glomeromycota) associated with roots of Ammophila arenaria growing in maritime dunes of Bornholm (Denmark). Acta Societatis Botanicorum Poloniae, 80, 63-76.

Blaszkowski J., Tadych M., and Madej T., 2002. Arbuscular mycorrhizal fungi (Glomales, Zygomycota) of the Błędowska Desert, Poland. Acta Societatis Botanicorum Poloniae, 71,71-85.

Bonfante P. and Perotto S., 1995. Tansley Review No. 82: Strategies of arbuscular mycorrhizal fungi when infecting host plants. New Phytologist, 130, 3-21.

Braunberger P.G., Abbott L.K., and Robson A.D., 1994. The effect of rain in the dry-season on the formation of vesicular-arbuscular mycorrhizas in the growing season of annual clover-based pastures. New Phytologist, 127, 107-114.

Bücking H. and Kafle A., 2015. Role of arbuscular mycorrhizal fungi in the nitrogen uptake of plants: Current knowledge and research gaps. Agronomy, 5, 587-612.

Camel S.B., Reyes-Solis M.G., Ferrera-Cerrato R., Franson R.L., Brown M.S., and Bethlenfalvay U.J., 1991. Growth of vesicular-arbuscular mycorrhizal mycelium through bulk soil. Soil Sci. Soc. America J., 55, 389-393.

Coutinho E.S., Fernandes G.W., Berbara R.L.L., Valério H.M., and Goto B.T., 2015. Variation of arbuscular mycorrhizal fungal communities along an altitudinal gradient in rupestrian grasslands in Brazil. Mycorrhiza, 25(8), 627-38.

Duponnois R., Plenchette C., Thioulouse J., and Cadet P., 2001. The mycorrhizal soil infectivity and arbuscular mycorrhizal fungal spore communities in soils of different aged fallows in Senegal. Appl. Soil Ecol., 17, 239-251. 
Ellis J.R., Roder W., and Mason S.C., 1992. Grain sorghumsoybean rotation and fertilization influence on vesiculararbuscular mycorrhizal fungi. Soil Sci. Soc. America J., 56, 783-794.

Gałązka A., 2013. Characteristics of glomalin and impact of different tillage systems on their content in the soil. Polish J. Agronomy, 15, 75-82.

Gałązka A. and Gawryjołek K., 2015. Glomalin - soil glicoprotein produced by arbuscular mycorhizal fungus. Postępy Mikrobiologii, 54(3), 331-343.

Gazey C., Abbott L.K., and Robson A.D., 1993. VA mycorrhizal spores from three species of Acaulospora: germination, longevity and hyphal growth. Mycology Res., 97(7), 785-790.

Giovanetti M. and Citernesi A.M., 1993. Time-course of appresorium formation on host plants by arbuscular mycorrhizal fungi. Mycology Res., 97(9), 1140-1142.

Gosling P., Hodge A., Goodlass G., and Bending G.D., 2006. Arbuscular mycorrhizal fungi and organic farming. Agric. Ecosys. Environ., 113, 17-35.

Guo H., He X. L., and Li Y. P., 2012. Spatial distribution of arbuscular mycorrhiza and glomalin in the rhizosphere of Caragana korshinskii Kom. in the Otindag sandy land, China. Africa J. Microbiol. Res., 6, 5745-5753.

Guo Y., George E., and Marschner H., 1996. Contribution of an arbuscular mycorrhizal fungus to the uptake of cadmium and nickiel in bean and maize plants. Plant Soil, 184(2), 195-205.

Hamel C., Dalpe Y., Lapierre C., Simard R.R., and Smith D.L., 1994. Composition of the vesicular-arbuscular mycorrhizal fungi population in an old meadow as affected by $\mathrm{pH}$, phosphorus and soil disturbance. Agric. Ecosys. Environ., 49, 223-231.

Jasper D.A., Abbott L.K., and Robson A.D., 1993. The survival of infective hyphae of vesicular-arbuscular mycorrhizal fungi in dry soil an interaction with sporulation. New Phytologist, 124, 473-479.

Khalil S. and Loynacham T.E., 1994. Soil drainage and distribution of VAM fungi in two toposequences. Soil Biol. Biochem., 26(8), 929-934.

Khalil S., Loynacham T.E., and McNabb H.S., 1992. Colonization of soybean by mycorrhizal fungi and spore populations in Iowa soils. Agronomy J., 84(5), 832-836.

Köhl L., Lukasiewicz C.E., and Heijden M.G.A., 2016. Establishment and effectiveness of inoculated arbuscular mycorrhizal fungi in agricultural soils. Plant Cell Environ.t, 39, 136-146.

Kowalczyk S. and Blaszkowski J., 2005. Arbuskularne grzyby mikoryzowe gleb województwa lubuskiego. Acta Agrobotanica, 58, 453-474.

Kowalczyk S. and Błaszkowski J., 2011. Arbuscular mycorrhizal fungi (Glomeromycota) associated with roots of plants of the Lubuskie province. Acta Mycologica, 46(1), 3-18.

Kowalska I., Konieczny A., Gąstoł M., Sady W., and HanusFajerska E., 2015. Effect of mycorrhiza and phosphorus content in nutrient solution on the field and nutritional status of tomato plants grown on rockwool or coconut coir. Agricultural Food Sci., 24, 39-51.

Kurle J.E. and Pfleger F.L., 1994. Arbuscular mycorrhizal fungus spore populations respond to conversions between low-input and conventional management practices in a cornsoybean rotation. Agronomy J., 86, 467-475.
Lahrmann U., Ding Y., Banhara A., Rath M., Hajirezaei M.R., Döhlemann S., Wirén N., Parniske M., and Zuccaro A., 2013. Host-related metabolic cues affect colonization strategies of a root endophyte. Proc. National Academy of Sciences USA, 110(34), 13965-13970.

Land S. and Schonebeck F., 1991. Influence of different soil types on abundance and seasonal dynamics of vesiculararbuscular mycorrhizal fungi in arable soils of North Germany. Mycorrhiza, 1, 39-44.

Lekberg Y. and Koide R.T., 2008. Effect of soil moisture and temperature during fallow on survival of contrasting isolates of arbuscular mycorrhizal fungi. Botany, 86, 1117-1124.

Lim Y.W., Kim B.K., Kim C., Jung H.S., Kim B.S., Lee J.H., and Chun J., 2010. Assessment of soil fungal communities using pyrosequencing. J. Microbiol., 48, 284-289.

Mathimaran N., Ruh R., Vullioud P., Frossard E., and Jansa J., 2005. Glomus intraradices dominated arbuscular mycorrhizal communities in a heavy textured agricultural soil. Mycorrhiza, 16, 61-66.

Mensah A.K., 2015. Role of revegetation in restoring fertility of degraded mined soils in Ghana. A Review. International J. Biodiversity Conservation, 7(2), 57-80.

Miranda J.C.C. and Harris P.J., 1994. Effects of soil phosphorus on spore germination and hyphal growth of arbuscular mycorrhizal fungi. New Phytologist, 128, 103-108.

Mirzaei J., Noorbakhsh N., and Karamshahi A., 2014. Identification of Arbuscular Mycorrhizal Fungi Associated with Crataegus pontica C. Koch from Ilam Province. Iran Ecopersia, 2(4), 767-777.

Mugabo J. P., Balkrishna S. B., Anil K., Havugimana E., Byiringiro E., and Yumnam N. S., 2014. Contribution of arbuscular mycorrhizal fungi (AM fungi) and rhizobium inoculation on crop growth and chemical properties of rhizospheric soils in high plants. IOSR J. Agric. Veterinary Sci., 7(9), 45-55.

Nichols K.A., 2004. Characterization of glomalin a glycoprotein produced by arbuscular mycorrhizal fungi. Agric. Soil Sci., 81, 123-129.

Nowak J. and Kunka M., 2009. Effect of mycorrhizal inoculation and eco-compost on the growth and flowering of spreading marigold (Tagetes patula L. cv. Petit Orange) cultivated in heavy metal contaminated substrate. Zesz. Probl. Post. Nauk Roln., 540, 369-372.

Oehl F., Sieverding E., Ineichen K., Ri E.A., Boller T., and Wiemken A., 2005. Community structure of arbuscular mycorrhizal fungi at different soil depths in extensively and intensively managed agroecosystems. New Phytologist, $165,273-283$.

Olsson P.A., Bååth E., and Jakobsen I., 1997. Phosphorus Effects on the Mycelium and Storage Structures of an Arbuscular Mycorrhizal Fungus as Studied in the Soil and Roots by Analysis of Fatty Acid Signatures. App. Environ. Microbiol., 63(9), 3531-3538.

Orgiazzi A., Bianciotto V., Bonfante P., Daghino S., Ghignone S., Lazzari, A., Lumini, E., Mello, A., Napoli, Ch., Perotto S., Vizzini A., Bagella S., Murat C. and Girlanda M., 2013. 454 Pyrosequencing Analysis of Fungal Assemblages from Geographically Distant, Disparate Soils Reveals Spatial Patterning and a Core Mycobiome. Diversity, 5, 73-98. 
Posta K., Marschner H., and Rornheld V., 1994. Manganese reduction in the rhizosphere of mycorrhizal and nonmycorrhizal maize. Mycorrhiza, 5, 119-124.

Purin S., Klauberg Filho O., and Stürmer S.L., 2006. Mycorrhizae activity and diversity in conventional and organic apple orchards from Brazil. Soil Biol. Biochem., 38(7), 1831-1839.

Rillig M.C., 2004. Arbuscular mycorrhizae and terrestrial ecosystem processes. Ecology Letters, 7, 740-754.

Rillig M.C. and Steinberg P.D., 2002. Glomalin production by an arbuscular mycorrhizal fungus: a mechanism of habitat modification? Soil Biol. Biochem., 34, 1371-1374.

Ronsheim M.L., 2012. The effect of mycorrhizae on plant growth and reproduction varies with soil phosphorus and developmental stage. American Midland Naturalist, 167(1), 28-39.

Ryan M. H. and Graham J.H., 2002. Is there a role for arbuscular mycorrhizal fungi in production agriculture? Plant Soil, 244, 263-271.

Saia S., Ruisi P., Fileccia V., Miceli G.D., Amato G., and Martinelli F., 2015. Metabolomics suggests that soil inoculation with arbuscular mycorrhizal fungi decreased free amino acid content in roots of durum wheat grown under N-limited, P-rich field conditions. PLoS One, 10(6): dx.doi. org/10.1371/journal.pone.0129591.

Sanchez-Diaz M., Goicoechea M.N., and Antolin M.C., 1996. Nutrients in drought stressed mycorrhizal and non-mycorrhizal alfalfa plants In: Arbuscular mycorrhizas in sustainable soil-plants systems. Raport of 1995 activities. Ed. Gianinazzi \& Schuepp. COST 821, Abstracts, 140.

Schachtman D.P., Reid R.J., and Ayling S.M., 1998. Phosphorus uptake by plants: from soil to cell. Plant Physiol., 116, 447-453.

Schoch C.L., Seifert K.A., Huhndorf S., Robert V., Spouge J.L., Levesque C.A., Chen W., 2012. Nuclear ribosomal internal transcribed spacer (ITS) region as a universal DNA barcode marker for Fungi. Proc. Nat. Acad. Sci. USA, 16, 6241-6246.

Schreiner R.P. and Koide R.T., 1993. Stimulation of vesiculararbuscular mycorrhizal fungi by mycotrophic and non-mycotrophic plant root systems. Applied Environ. Microbiol., 59(8), 2750-2752.

Shetty K.G., Hetrick B.A.D., and Schwab A.P., 1995. Effect of mycorrhizae and fertilizer amendments on zinc tolerance of plants. Environ. Pollution, 88, 307-314.

Smith S.E. and Read D.J., 2008. Mycorrhizal symbiosis. Academic Press, 11-188.

Solaiman M.Z. and Hirata H., 1996. Effectiveness of arbuscular mycorrhizal colonization at nursery-stage on growth and nutrition in wetland rice (Oryza sativa L.) after transplanting under different soil fertility and water regimes. Soil Sci. Plant Nutrition, 42(3), 561-571.

Tadych M. and Blaszkowski J., 2000a. Arbuscular mycorrhizal fungi of the Brda river valley in the Tuchola Forests. Acta Mycologica, 35, 3-23.

Tadych M. and Błaszkowski J., 2000b. Succession of arbuscular mycorrhizal fungi in a deflation hollow of the Slowinski National Park, Poland. Acta Societatis Botanicorum Poloniae, 69, 223-236.

Tahat M.M. and Sijam K., 2012. Mycorrhizal fungi and abiotic environmental conditions relationship. Res. J. Environ. Sci., 6(4), 125-133.

Talukdar N.C. and Germida J.J., 1994. Growth and yield of lentil and wheat inoculated with 3 Glomus isolates from Saskatchewan soils. Mycorrhiza, 5, 145-152.

Thompson J.P., 1996. Correction of dual phosphorus and zinc deficiences of linseed (Linum usitatissimum L.) with cultures of vesicular-arbuscular mycorrhizal fungi. Soil Biol. Biochem., 28(7), 941-951.

Turnau K., Kottke I., and Oberwinkler F., 1993. Element localization in mycorrhizal roots of Pteridium aquilinum L. Kuhn collected from experimental plots treated with cadmium dust. New Phytologist, 123, 313-324.

Vallini G., Pera A., Avio L., Yaldrichi M., and Giovanetti M., 1993. Influence of humic acids on laurel growth, associated rhizospheric microorganisms, and mycorrhizal fungi. Biol. Fertil. Soils, 16, 1-4.

Wright S.F. and Anderson R.L., 2000. Aggregate stability and glomalin in alternative crop rotations for the central Great Plains. Biol. Fertil. Soils, 31, 249-253.

Wright S.F., Franke-Synder M., Morton J. B., and Upadhyaya A., 1996. Time course study and partial characterization of a protein on hyphae of arbuscular mycorrhizal fungi during active colonization of roots. Plant Soil, 181, 193-203.

Yang Y., Han X., Ghosh A., Chen J., and Tang M., 2015. The combined effect of Arbusculat Mycorrhizal Fungi (AMF) and lead $(\mathrm{Pb})$ stress on $\mathrm{Pb}$ accumulation, plant growth parameters, photosynthesis, and antioxidant enzymes in Robinia pseudoacacia L. PLoS One, 10(12): e0145726. doi:10.1371/journal.pone.0145726.

Zholl J., Snelders E., Verweij P. E., and Melchers W.J.G., 2016. Next-Generation Sequencing in the Mycology Lab. Curr Fungal Infect Rep., 10, 37-42.

Zubek S., Turnau K., and Blaszkowski J., 2008. Arbuscular mycorrhiza of endemic and endangered plants from the Tatra Mts. Acta Societatis Botanicorum Poloniae, 77, 149-156. 